\title{
TOWARDS A NEW RELIGIOUS NARRATIVE IN THE UNITED
} STATES OF AMERICA?

\author{
¿HACIA UNA NUEVA NARRATIVA RELIGIOSA EN LOS ESTADOS \\ UNIDOS DE AMÉRICA?
}

\author{
SERGIO GARCÍA MAGARIÑO \\ I-Communitas, Institute for Advanced Social Research \\ (Public University of Navarre)
}

Recibido: 21/02/2020

Aceptado: 22/04/2020

\begin{abstract}
American secularization is considered an exceptional case in the Western world because of, on the one hand, the softer way it seems to have occurred in relation to other Western countries and, on the other, the fusion which is done among Judeo-Christian traditions into what is known as American civil religion. The point proposed before is problematic and needs to be called into question under the light of both the revisions made to the secularization theory by scholars such as Casanova through the interpretation of empirical data collected in the world about the religiosity of people and the multiple works published about the use of "sacred" language in American public life. However, this paper takes those problematic dimensions for granted to delve into what can be considered another secular human endeavor endowed with a religious spirit, namely: the spirit of Silicon Valley. This new secular-sacred narrative is not just American but is being exported as a narrative with "Messianic" traces that seems to aspire to embrace the whole world. Thus, this article explores the origins and evolution of this narrative in the United States, on the one hand, and the expansion of what can be considered a "salvation" ideology abroad, on the other.
\end{abstract}


Keywords: phenomenology, metaphysics, donation, affectivity, hermeneutics, theology.

\section{RESUMEN}

La secularización estadounidense se considera un caso excepcional en el mundo occidental debido, por un lado, a la forma más suave en que parece haberse producido en relación con otros países occidentales y, por otro, a la fusión que se realiza entre las tradiciones judeocristianas en lo que se conoce como religión civil estadounidense. El punto propuesto anteriormente es problemático y debe ser puesto en cuestión a la luz tanto de las revisiones realizadas a la teoría de la secularización por estudiosos como Casanova (a través de la interpretación de los datos empíricos recogidos en el mundo sobre la religiosidad de las personas), como de los múltiples trabajos publicados sobre el uso del lenguaje "sagrado" en la vida pública estadounidense. Sin embargo, este trabajo da por sentadas esas dimensiones problemáticas para ahondar en lo que puede considerarse otra empresa humana secular dotada de espíritu religioso, a saber: el espíritu de Silicon Valley. Esta nueva narrativa secular-sagrada no es sólo estadounidense, sino que se está exportando como una narrativa con trazos "mesiánicos" que parece aspirar a abarcar el mundo entero. Así, este artículo explora los orígenes y la evolución de esta narrativa en Estados Unidos, por un lado, y la expansión de lo que puede considerarse una ideología de "salvación" en el extranjero, por otro.

Palabras clave: fenomenología, metafísica, donación, afectividad, hermenéutica, teología.

\section{INTRODUCTION}

Secularization is part of a great sociological theory that tried to explain the different social phenomena linked to the movement from traditional, rural societies to modern, urban ones. As Max Weber proposed, as societies moved along that path of social change, citizen's loyalty towards traditional religious institutions would progressively weaken (Estruch 2015).

This descriptive theory, however, when the interdisciplinary area of development was founded after Second World War, became a prescription to "modernize" countries, as it was assumed that modernization would bring development and social progress automatically. Thus, secularisation moved from being a social process that seemed to have occurred in several countries - 
especially European — , to a desirable outcome to be fostered through political and civil action.

The American case, though, was considered a special one within the Western world, as it was the first and most modern country but its religious life was still very vibrant. Further, religious symbols, practices, narratives, references and collective rituals were introduced into the life of secular institutions such as laws, tribunals and National feasts (Bayon 2016).

In order to explain the apparently exceptional phenomenon of American society in relation to its people's religiosity, the concept of American civil religion was devised. American civil religion was a kind of fusion among Jewish, Catholic and Protestant traditions into a non-sectarian spiritual tradition that generates social cohesion (Bellah 1967).

Over the first two decades of the twenty-first century, at least three social processes might have had an impact on American society that deserve careful attention and, perhaps, a revision of American civil religion theory: (a) Important changes at the level of people's religiosity, (b) a renewed and growing interest in religion and (c) a new form of religious messianism linked to the expansion of the ideology underpinning Silicon Valley.

\section{FORMS OF RELIGIOSITY}

It was mentioned that secularisation theory changed into a normative ideology. Scholars, such as Berger, Habermas or Casanova did not make such a big claim. However, all of them agreed upon the idea that secularization was taken for granted (Berger 1995; Casanova 2000; Habermas 2011). Thus, important transformations at the level of people's religiosity went unperceived. It is necessary to recognize that gathering international data about people's religiosity in order to identify patterns is not an easy task, so the problem was not only a neglect -as a result of taking secularisation for granted- but also methodological.

Even if agreeing on the same set of questions to make surveys about people's religiosity throughout the world, what is meant by the word "religious" is quite different from one region to another (Casanova 2009, 9). However, there are certain polls and surveys which seem to show a pattern. Given the complexity of the task at work, these perspectives, though, should be taken as provisional.

For instance, Gallup polls in 1999 and 2005 indicate that over $65 \%$ of the people who replied to the questions "give God high importance" or consider 
themselves to be "religious people". The percentages vary among regions and countries. In Sub Saharan Africa, South Asia, the Middle East, the vast majority of people consider themselves religious. The same happens in our case, in the States, where most people, according to the pull, "give God high importance". However, the global trend seems to be decreasing. ${ }^{1}$

Pew Research Center offers a good glimpse of the trends too. Alike Gallup polls, Pew's analysis shows that the vast majority of people believe in $\mathrm{God}^{2}$. In addition, the total number of people who believe in God is constantly increasing, but probably as a result of the planet's increase in the total population.

When regions are taken into consideration, the situation slightly varies. The majority of people in Sub Saharan Africa, in South Asia, in the Middle East and in the United States consider themselves more religious than before while in the rest of the regions the trend is softly decreasing.

This estimates, though, are not definitive as it seems that, depending on the question asked, the responses could suggest other trends. However, it can be confidently said that religion is still present and plays an important role in the life of the masses. Nevertheless, the form might not be exactly the same as in the past. There are new religious groups, there are new forms of spirituality and traditional religions have evolved to incorporate new elements coming whether from spiritual or secular traditions (Díaz Salazar, Velasco, Ginés 1996).

Thus, secularisation should not be taken for granted or, at least, naive notions of secularisation should be overcome in order to open the path for more sophisticated theories. As Casanova, Joan Estruck (1996) and other scholars of the theory of secularisation have posed, neither should be assumed that religion has turned into a private issue or a secularised set of sacred rituals: religion still has a collective imprint which aspires to contribute to facing the challenges of current global modern society.

The conceptualization of Western countries, especially the European ones, as "post-secular" - Habermas also includes Australia, Canada and New Zealand (Habermas 2009, 64) - , tries to capture the transformations taking place at the level of people's religiosity (Berger 2012). However, the case of the States, which was formerly considered the exception, seems to be the pattern: religion is not declining, indeed the global trend is that religion is growing - with the exception of European countries, where society is secularized but the persistence of religion in public life is still prevalent (Roldán 2016; Moghadam 2003; Pew Research Center).

1 https://news.gallup.com/poll/1690/religion.aspx

2 https://www.pewforum.org/religious-landscape-study/belief-in-god/ 
The three criteria commonly used to consider a society as "secular" are (a) the progressive differentiation of social spheres and, more in particular, the separation between the State and the Church; (b) the replacement of magical thinking for technoscientific rationality and the achievement of technical progress; and (c) the reduction in society's beliefs.

European societies seem to be the only ones which meet previous criteria but, despite that, religions in Europe still have an impact on public sphere, whether because of Jihadist terrorism and its use of modern technology or the Catholic Church's efforts to influence public morality (Habermas, 2009), and that is why they (European societies) deserve the term "post-secular".

Sticking to the criteria posed before, the United States would not be a postsecular society, as the third requirement - reduction of beliefs-, according to Roldán Gómez (2017) —who makes a meta-analysis of data coming from different polls - is not present. However, it is neither a traditional society, since the separation between the State and the Church (churches) and the technical and economic - progress are both very strong. The United States, therefore, breaks the apparent dichotomy between modernity and religion because, whereas it is a modern country, religion still plays an important role in private and public life.

\section{RENEWED INTEREST IN RELIGION}

At the level of the elites, during the second half of the twentieth century, a materialist conception of existence had consolidated. This philosophy found expression in at least four visible spheres: historical materialism, capitalism, the development interdisciplinary area and postmodern consumerist society. However, the promises of these four trends, as the century came to the end, appeared unfulfilled.

First, the fall of the Soviet Union, together with the cruelties occurred during certain communist regimes which had been hidden for decades, reduced the appeal of Communism and the confidence in the transformative utopia that it contained. Second, global liberal capitalism did not bring the prosperity and social justice that it was supposed to; on the contrary, it widened the gap between the wealthiest and the poorest. The unfulfilled forecast of Fukuyama in "The end of history" (1989) symbolizes this point.

Third, the exciting enterprise of development, whose explicit purpose was to eradicate poverty, but which departed from the same materialistic assumptions, 
did not fulfill its goals and was not even able to instill in those whom the projects had to serve the motivation to participate in them.

Finally, as a result of the loss of confidence both in the possibility to change the world and in the very rational capacityto make universal rational statements, postmodern thinking paved the path for the conclusion that the only feasible proposal was to forget those aspiration and to focus on trying to be happy by traveling, enjoying cultures and, ultimately, by consuming. Given the prevalence of depression, anxiety, general sense of dissatisfaction and mental problems within the most consumerist societies (Gonzalez 2010, 3), it could be said that an existential vacuum seems to have pervaded many countries in the world.

Another world trend that has contributed to the crumbling of this "materialistic enterprise" described above, has been global integration. Economic globalization is a process whose roots can be found some centuries ago but which has dramatically intensified over the last fifty years, mainly as a consequence of the upsurge of new technologies in the fields of communication and transport. However, economic capital is not the only thing that has been globalized. As Martin Albrow proposes in The Global Age (2012), all social processes, such as economy, culture, science, communications, technology, migration, threats, have become global except for politics.

Beyond the recognition that this globalization is lacking global governance, what seems to be clear is that the movement of populations - with their cultural, religious, ethnic and social background - has approached cultures, religions, values, and practices which in the past were constrained to a very particular geographical setting and that had little or any interaction amongst themselves . This forced "gathering" of peoples has normalized a phenomenon which used to be a exceptional event experienced by travelers: cultural clash.

In sum, global integration and the breaking of the "materialistic enterprise" have stimulated a new search and interest in religion or at least in transcendental and "spiritual issues". Some indicators of this renewed interest are the number of publications, undergraduate and graduate programs in "religious studies" that appeared over the twenty-first century; the upsurge of many conflicts connected to religion; the concern with Islam and more particularly with political Islam; the proliferation of practices such as travels to India to visit certain "gurus"; the emergence of aboriginal rituals and group "experiences" in Western countries where ceremonies are held; the use of drugs in search for "spiritual experiences", the renewal of the Interfaith international movement; the connection between politics and religion in different countries; the expansion of fundamentalisms of different kinds in different regions; the appearance of new political movements in 
Europe which either have religious foundation or use slogans against specific religious groups; the enhancement of awareness at the level of public institutions on the potential conflict of religious and cultural clashes when diversity is not correctly managed; to name a few (Díaz-Salazar et al., 1996).

What is equally surprising is that the traditional channels of these transcendental impulses —organizational religion — are not being used. Moreover, new narratives, apparently secular but containing features of the "sacred ones", such as the one that is going to be analyzed in the following point are being multiplied. In other words, the new search for meaning and spirituality, the new interest in religion, is not being channeled by the institutions that traditionally have been the focal point of this impulse towards transcendence. Some authors, such as Juan José Tamayo, interpret this new trend as a sign of democratization: spirituality is not the monopoly or religion anymore (2011). Others consider that this is a distortion of the spirit of religion and the consequence of religions not taking into account the requirements of the modern world (CMB 2005).

In any case, it might be said that modern societies contain a sort of existential vacuum that was filled by religion in the past and that propels the constant production of sacred narratives. This vacuum is related to Weber's "disenchantment", to Hartmut Rosa's theory of resonance (Rosa 2019), to Joas' explanation of why we need religion to strengthen values commitments and justification (Joas 2008) and to Jasper's and Madsen's forecast of a potential new Axial Age (Joas and Bellah 2012, 430). The upsurge of so-called Silicon Valley's messianism will be interpreted under this lens. In addition, the application of the so-called "critique of ideologies" to religion, although in some instances unveiled the connection between some religious institutions and power and discovered the use of religious claims to justify hidden agendas, eliminated all the positive effects of religion. For instance, its power to collectively identify "false idols" seems to have disappeared from society. Hence, it is extremely difficult to unmask secular movements with particular agendas but disguised with apparent pure motives.

\section{SILICON VALLEY'S NEW MESSIANISM}

The United States was founded upon ideas which combined political and religious references, as it was exposed above. America was interpreted by some as the New Jerusalem, the Promised Land, the land of opportunities... (Bayón 2018). Masonic lodges seem to have played an important role in the construction of this sacred notion of national identity (Ferguson 2019). This claim is proposed by different authors - mainly masonic, so the claim combines historical facts with 
a mythological narrative - but, according to historians as Ferguson and the virtual masonic museum of $\mathrm{UNED}^{3}$ (Spain), the number of archives is not enough to ascertain it with great rigor. Beyond the veracity of the sources, what it is undeniable is the correlation between some masonic symbols and American collective imaginary: dollars, some symbols within American Central Bank, the top of Washington Monument, the widespread popular narrative ascribing masonic background to many "heroes of the Nation", such as presidents, bankers and, in general, people of high influence (Bayón 2018; Bayón, Fuente, and Campos 2018).

This self-image of a kind of modern chosen people was reinforced by the economic growth that the States experienced during the twentieth century, as a result of its victory in Second World War and, finally, of the leading global role it assumed after the fall of Soviet Communism. Nevertheless, the terrorist attacks of September 11 apparently changed the collective psychological atmosphere. The new era, the end of the history of conflicts narrative was replaced by another one, linked to the awareness of multiple threats and vulnerabilities which resembles another religious narrative: the apocalypse. In other words, climate change, Jihadist threat, migration, new world conflicts, weapons of mass destruction, economic crisis, identity clashes, passing diseases came to the top of public agenda, opening the path for and generating the right atmosphere for the upsurge of messianic movements and new narratives of salvation. In the next paragraphs it will be proposed that the so-called "Spirit of Silicon Valley" might be considered one of these messianic movements.

\section{ORIGINS}

What will be called The Spirit of Silicon Valley seems to have been the result of a century of intense history marked by five major forces: a countercultural and four technological and economic projects.

Silicon Valley is a specific warm region in San Francisco that embodies economic, industrial and economic success. It gathers over six thousand Tech companies, some of which are international symbols: Apple, Google, Cisco, Facebook, Netflix, Oracle, Tesla, Instagram, Twitter, Intel... (Sadin 2019). San Francisco also hosts the most important American digital research labs, two of the most prestigious universities in the world (Berkeley and Stanford), has cultivated very selective immigration policies to bring "brains" from China and

3 https://www2.uned.es/dpto-hdi/museovirtualhistoriamasoneria/6historia_\%20masoneria_ paises/origenes $\% 20 \mathrm{M} \% 20 \mathrm{en} \% 20 \mathrm{EEUU} . \mathrm{htm}$ 
India and, finally, it has become a very appealing destiny for people from every corner of the world who want to live the "American dream".

The Vietnam war, the economic crisis of 1973, the failure of Donald Reagan's attempt to make "America great again" weakened the promise of the States as the land for salvation. However, the territory for the promise, the new Jerusalem, seemed to focus on a narrower space: San Francisco.

The history of San Francisco is full of pioneering anecdotes. It was the golden land in the nineteenth century, and so the name of its famous bridge: The Golden Gate. It was the center of the counter-cultural movements in the sixties. In the seventies, San Francisco represented the place were American traditional values and norms had to be called into question. The campus of Berkeley gathered youth who wanted to make their life free from the constraints of American political and cultural rules. Songs, movies, books reflect these ideas, especially in reference to California. The "Flower power", "Summer of love" movements which dreamed about changing the world, establishing peace, the emancipation of human beings from the fetters of oppression emerged in that region (Sadin 2018).

The cultural movement which took place in San Francisco in the sixties, although diverse, was built upon certain underlying assumptions (Braunstein and William 2002, 10). Firstly, capitalism was considered oppressive as well as communism, so new forms to express human individuality were needed. Hedonism and enhancing individual freedom to choose communities of belonging were proposed instead. Secondly, it was perceived that American democracy was in crisis and this sort of ideological vacuum opened the path for proposals such as the one made by Mills in Sociological Imagination (1959). Libertarian utopias were brought back to inspire a new political left to engage in social action aimed to break oppressive barriers that prevent human emancipation. Examples of "causes" to be pursued were as diverse as war, racism, pollution, racism, consumerism, homophobia or sexual discrimination. It is worth mentioning that opposition to the Vietnam war was quite prevalent. Thirdly, arts and culture played a crucial role. New music bands and movies were both the result of this environment and the mechanisms to strengthening it and to spread out its ideals. The Who, the Mamas and Papas, Simon and Garfunkel, the Beach Boys, Bob Dylan, psychedelic rock are just but a few examples from the realm of music which became very popular. At the same time and in the same context new sports imbued with former values emerged: noncompetition, having fun together, flowing, mingling sexes... Frisbee was one of these sports. However, there is another genre which grew more in popularity, 
Californian Sports, namely: skating, surfing, climbing, rolling, etc. Fourthly, the Campus of Berkeley, as it was pointed out above, served as the intellectual substance to legitimize this trend or at least as an important battlefield where student, through demonstrations, showed their discontent. Different director experimented in the campus trying to capture the needs of the time. Nonetheless, some of them interpreted these requirements in terms of adjusting the programs and curriculum to the emerging market of techno industry, while others tried to materialize the culture of diversity and freedom distinguishing California in the way the Campus was managed (Kerr 2001). Finally, the cultural effervescence of the region cannot be totally understood without reference to the extensive and growing use of drugs, mainly LSD. This psychedelic movement aspired to widen consciousness and to transform society, mainly by taking acid and acting under its influence, whether upon arts, social organization or parting (Grames 2011).

As it was mentioned, in addition to the cultural upheaval, four technoscientific-economic projects preceded the upsurge of the so-called Spirit of Silicon Valley. The first one is related to an effort made in the thirties to gather in the same place top scientists, engineers, researchers, investors, and industries in order to, on the one hand, generating synergies which might create an innovative economic model, and, on the other, to serve a growing army and weapon industry. Particularly in the thirties, Stanford became the settling around which "Silicon Valley" was formally established. Very soon, big companies moved there, such as IBM or Texas Instruments (Sadin 2018, 61). The government also made an important investment in infrastructure, public institutions, schools, irrigation systems to feed this process. Frederick Terman, vice-principal of Stanford University encouraged students to assume risks, to become entrepreneurs, inaugurating the future myth of "company-garage". This notion of garage symbolizes Silicon Valley's philosophy as it portrays the image of an "individual" breaking prevalent economic framework and social constraints, galvanized by courage and initiative trying to prosper and to create a new model.

The second project revolves around computing. People like Bill Gates and later Steve Jobs, inspired by the philosophy of the "garage", but enthralled with the potentialities of new electronics, contributed to a movement which aspired to emancipate human beings through the creation and use of liviane technological devices that (a) make life easier, (b) generate new economic dynamics, (c) connect people and (d) impulse human progress and happiness (McLuhan 1996; Borroughs 2009). During this period, a new kind of activism also appeared: techno libertarians, who were influenced by cyberpunks and 
libertarians. The figure of a hacker might be considered the ideal —in Weberian terms - of the movement.

The third phase or project happened in the nineties. The economic policies of President Bill Clinton are an indicator of its nature. He took the building of "information highways" the heart of the American economic strategy. Data was considered the key competitive factor of any economy. Interconnectedness, networks and digital technologies were going to bring - it was thought - more prosperity, democracy, and equality. Time and space would not constrain human action anymore. San Francisco and Silicon Valley, again, became the focal points of practical initiatives inspired by this new move. The first browser for the great public was engendered there: Mosaic. Within the same settlement, Yahoo was invented, Amazon was founded, Google appeared, Paypal emerged and tremendous investments were made, as a result of blind faith in the bounties of the wired economy (Sadin 2018, 75).

Finally, the fourth project, at the beginning of the XXI century, related to what started to be known as the new "knowledge economy". Cognitive capitalism, the capability to massively use data were considered as the defining feature of a sound economic strategy. Thus, social networks multiply, Google refined its mechanisms to trace data, and companies related to this capacity to draw on users' information, such as Facebook, Myspace or LinkedIn - all of them located in Silicon Valley - became the most admired centers of the world. The notions of Start-Up as a company trying to create applications for smart devices, intelligent infrastructures, smart cities, smart architecture, the internet of things, got prevalent. Regardless of the hidden monopoly that it has been generated, the ideals of disintermediation, democratization, equalization spread out like wildfire. This new economy of data differs from the third phase, as it included an explicit reference of the "infinite" possibilities for economic life. Therefore, through the increasing capacity to trace and draw on data about human behavior, algorithms to organize "rationally" collective life and the invention of application for individual use, the economic horizon of humanity might be constantly widening.

Both this cultural background and the four projects described above paved the way for what is named here "The Spirit of Silicon Valley" and that will be analyzed below. Although it will be examined under the light of a new pseudoreligion, in secular terms the "Spirit of Silicon Valley" might be seen as the attempt to globalize the fourth project identified previously. 


\section{THE SPIRIT OF SILICON VALLEY}

The "Spirit of Silicon Valley" is something different from this past that San Francisco has. However, the past is connected to current narrative. These movements which bore transformative utopias did not succeed completely. They achieved certain social victories, such as the widening of political and civil rights, but their revolutionary potential was dismantled by another logic: pragmatic libertarianism (Grames 2011). This logic is an economic logic embedded into a grand narrative that makes it difficult to identify its main goal: to make infinite money through the creation of tech start-ups that explode the generation of data and artificial intelligence (Sadin 2018, 25).

This relation between narratives and power has also been explored by other scholars who are usually categorized as "postmodern", such as Michael Foucault, David Harvey, Jean-François Lyotard or Carlos Granés. One of the key points they have "unveiled" is the complex dynamics between knowledge and power (García 2016, 132). Pre-modern conceptions of the relation between power and knowledge proposed that power came from God, therefore those in positions of authority, on the one hand, received their legitimacy from religious worldviews and, on the other, were endowed with almost "revealed knowledge". Modernity altered this connection, by enhancing the role of knowledge. Thus, the legitimate use of power by those with authority - from modern perspectives - derives from expert knowledge and rational use of it. However, postmodern thinking broke this link again by discovering that those who are in positions of authority use their power to impose narratives, notions of knowledge which benefit their interest (Harvey 1998). This kind of "unmasking" strategy emanating from postmodern thinking permits to go beyond the näive claims of those promoting Silicon Valley's apparent altruistic philosophy.

Thus, Silicon Valley's narrative particularly highlights the possibility to accompany our life through artifacts that are guided by algorithms which offer, in every single moment, the best world possible. In addition, this economic model which aspires to conquer every market, every sphere of human activity, has broken the natural limits of our previous economic systems. For instance, there are infinite options to generate data; there is no need for time - everything can be instantaneous - ; there is no space - data can penetrate everything, even dreams - ; there are no physical limitations - just energy and silicon. The greatest hopes of liberalism are fulfilled in the techno-libertarian claims.

This trend would not be considered a new messianism if the aspiration remained circumscribed to a territory. By the "Spirit of Silicon Valley", Eric Sadin — who coined the term - referred to a project to expand the model 
described previously — including its philosophy — throughout the world. This kind of digital colonization of the world would be the essence of that spirit which resembles the messianic movements that aimed to save humanity. The difference is that on this occasion humanity is expected to be saved via machines that interpret data and guide our actions. Therefore, this movement might be dangerous because, as it expands, free will contracts.

Sadin's perspectives are probably too apocalyptical. Nonetheless, they warn on naive proposals that seem to blindly promote the use of technology as "the way" to improve society. As the author of this paper has said in other publications, nowadays there are at least four concealed philosophical positions on technology which affect people's' attitudes toward it: equating technology to progress, equating technology to regression, technological neutrality and recognizing the values that every technological device inherently bears (García 2018). Technology literacy could assist society to make better and more intelligent choices.

From another angle, Marina Garcés proposes that the "Spirit of Silicon Valley" is a dangerous civilizational project which aspires to conquer the world and every single sphere of social life, since it displaces human beings from the center of social organization by placing technology instead (2017). Taking Garcés' proposal to the last consequences, civilizations have historically been connected to specific worldviews detaching from particular religions (García 2016; Huntington 2002; Duplessy 1959). Thus, the "civilizing" project must bear inside some features associated with religions: expansion, evangelization, transcendence, collective identity, sense of mission, rituals, practices... Some of these features will be examined below by following the pattern of MacIntyre in Marxism and Christianity, where he identifies features of Christian religion in Marxism (1984).

Economy, technology, and politics seem to have established an alliance to spread the economic model of Silicon Valley and its underlying ideas all over the world. This is a sort of "evangelization" and "sense of mission". There is a huge system of propaganda - proselytism - which is turning out to be very effective to fund in city after city of the five continents small "Silicon Valleys". A network of Universities, a system of top conferences - Ted Talks-, exalt the bounties of technological parks, defend the need for start-ups and the intelligent policies that get to generate the conditions for company incubators. The priests are those youths who became extremely wealthy and explain their story mixing keys for economic success with slogans about how an app can change the world. 
Whether in Berlin and Santiago de Chile, in Haifa or in Lagos, in Dubai or Bangalore, many Silicons are emerging in the five continents.

Thus, these technological parks might be considered the temples of the new religion. Google, Facebook, and the big tech companies, in addition, might resemble the institution of the Church. The successful business people are the new priest class and the entrepreneurs, the disciples. The Universities which were mentioned above may be seen as the training institutions of the new clergy and, their theology, the narrative which is conveyed and that mixes contradictory intentions with three main ideological characteristics.

Concerning the intentions, the public conferences and the discourse amongst the youth who are part of the movement highlight a desire to improve and to change the world through technology and the economic model of "prosperity" which it brings. This aspect of the narrative connects with the history of Silicon Valley. However, there are other intentions that are not published so widely. First of all, the desire to become rich. This is a wish that, on the one hand, grows spontaneously in the hearts of the youth who want to do the same as Zuckerberg; but on the other, is deliberately cultivated by the big companies which want to expand their tentacles. Facebook, for instance, might have started as a result of the need to connect friends. However, very soon the motivation to make Facebook grow was to generate a system to gather data to be sold to companies. This latter point was the driving force that has shaped Facebook since 2004. To sum up, it can be said that the public narrative, which contains noble aspirations, hides the actual intentions: to become rich.

The theology within this kind of new religion is quite consistent and appealing. First of all, it is grounded on a belief in the bounty of technology one of the four philosophical attitudes explored above. Its logic is: the more technology, the better. It was mentioned that the debates within the philosophy of technology ranges from equating technology with progress to see technology as the source of conflicts, from considering technology as a value-free system to connect every single artifact with values that are strengthened by the use (García 2018). This case clearly sticks to the first of these four options and the author of this paper, as he has published in other means, to the fourth.

Beyond that previous belief which pervades the whole system of thought, the theology of "Silicon" states that: (a) the technology of data associated to the internet of things has infinite possibilities, (b) through artificial intelligence and algorithms those data can be interpreted to suggest better decisions - together with items to be consumed - to human beings, and (c) those decisions suggested by algorithms will assist people to make better choices and so to live happier. 
At this point, it has to be clarified that the conception of religion held in this paper is not an ontological but a functional one (Estruck 2015; Berger 1974). Functional notions of religion are used in sociology to explore social phenomena that resemble religions and which play similar functions: a sense of transcendence, collective identity, practices, the separation between the sacred and profane aspects of life, etc. Thus, research on religion in secular or modern societies not only entails the study of people's beliefs, the loyalty to traditional institutions or the emergence of new formal religious groups, but also the analysis of other phenomena that play a similar role. Therefore, considering the "Spirit of Silicon Valley" as a new religion is not meant a formal, organized new religious group, but a social phenomenon with resemblances to religion and that can be examined from that angle for heuristic reasons.

Another point to be clarified is that the purpose of this analysis is not to assess the danger inherent to this model - especially concerning the alluded reduction in the human capacity to make decisions-, neither to judge whether the narrative is just a mask to hide deeper intentions - to be a millionaire at any cost-, but to uncover the sacred and quasi-religious dimension with which it is endowed. Nevertheless, it is clear that the ideology conveyed by this new sort of messianism bears a dangerous civilizational proposal which constantly reduces human free will.

The American television sitcom Silicon Valley shows that the cliche "we want to make the world a better place" is prevalent and omnipresent, according to Sadin's sociological study (2019), in the work of the youth who run start-ups. The almost religious philosophy of happiness and salvation of the "Silicon Spirit", thus, contains the prospect that through digital technologies and data processing, the world could progress indefinitely. Although the collective and communitarian dimensions of this might be present in the movements of San Francisco of the past, the current trend is quite individualistic. This matches with the Protestant tradition upon which the American nation was built, namely: individuals taking the initiative to prosper and to assist their fellow citizens.

Finally, the "Spirit of Silicon" has implications on policy and, indeed, poses certain political action. The role of the government, it is affirmed, would be to create the conditions out of which the start-ups' system could grow. This is the sort of triple marriage which was indicated previously. Although apparently innocent, the risk appears when this proposal to attain progress and happiness is considered as the only way to attain progress and happiness. 


\section{CONCLUSIONS}

Religious narratives have not disappeared in modern societies. Religion seems to be a permanent feature of humanity's individual and collective life and plays an important role in social processes. The predictions of extreme secularist theories were not fulfilled. Thus, secularisation is being revisited to attain a deeper understanding of its dynamics. According to data coming from different sources, the only region of the world where religious beliefs seem to have decreased in Europe. However, even in these societies, religion has not disappeared from the public sphere and learning to manage religious diversity is a crucial point to strengthen social cohesion.

The consolidated materialistic worldview of the twentieth century held by the elites, as a result of global integration and the problems related to communism, liberal capitalism, development practice, and consumerism, have opened the path for a new search for meaning and spirituality and for a renewed interest in religion during the twenty-first century. However, this search is not being channeled through the traditional means out of which spirituality found expression.

The United States, one of the first modern countries, followed a particular path as far as in what the relation of religion and public sphere is concerned. The notion of civil religion was coined to describe this symbiotic relation. Other terms, such as post-secular societies, when rigorously applied, do not apply to North America.

From a functional perspective, in the last decades, a new quasi-religion narrative grew in the States, especially in a particular region: San Francisco. This narrative has been characterized as the "Spirit of Silicon Valley". Sacred references; an extreme trust on the relation between economic prosperity, happiness and technology; ambition; a desire to save the world and to make it a better place; technological innovation; and government complacence; have all combined to engender a new global project which is trying to colonize both the whole world and every sphere of social and individual life. Given the magnitude of the project and the manifold facets of social life over which it has implications, it has a civilizational dimension.

The context out of which the "Spirit of Silicon Valley" emerged, has been characterized as the sum of certain cultural setting which developed in San Francisco over the fifties and sixties led by countercultural movements and four techno-economic projects: the creation of Silicon Valley to attract investors, scientists, engineers, industries — mainly, military — as a way to advance 
towards a new economic model; the revolution of electronics and computing; the promotion of information infrastructures and network economies in the nineties; and the appearance of cognitive capitalism marked by the generation, analysis and use of data. These trends, but especially the last one, opened the path for the "Spirit of Silicon Valley" which seeks to globalize and universalize Silicon Valley's economic model and philosophy.

Comparing the Silicon project with other religions, there is (a) a proselytizing dimension to expand the economic model, (b) a priesthood comprised by the successful business youth, (c) a community of disciples represented by tech entrepreneurs, (d) a set of temples across the globe exemplified by the technological parks, (d) a series of training institutions for the new clergy in the shape of Universities, (e) a kind of churches embodied by the big companies such as Facebook and Google, and finally (f) a sort of theology underpinned by three main points: the technology of data associated to the internet of things has infinite possibilities, through artificial intelligence and algorithms those data can be interpreted to suggest better decisions - together with items to be consumed - to human beings, and those decisions suggested by algorithms will assist people to make better choices and so to live happier

Therefore, the generation of data and artificial intelligence are the driving forces of a limitless techno liberal enterprise that threatens humanity's range of action by the ever-evolving robotic capacity to suggest "the best option" for each person in every moment. However, the appealingness of the narrative and the apparent nobility of its aspiration make it difficult to uncover the underlying desire to make money at any cost.

\section{BIBLIOGRAPHY}

Albrow, Martin. 2012. Global age. Cambridge: Polity Press.

Bellah, Robert. 1967. "Civil Religion in America". Journal of the American Academy of Arts and Sciences 96, $\mathrm{n}^{\circ}$ 1: 1-21.

Berger, Peter. 1974. "Some second thoughts on substantive versus functional definitions of religion". Journal for the scientific study of religion $13, \mathrm{n}^{\circ} 4$ : 125-133.

Berger, Peter, and Thomas Luckmann. 1995. Modernity, Pluralism and Crisis of Faith. The Orientation of Modern Man. Gütersloh: Bertelsmann Foundation Publishers.

Berger, Peter. 1999. The Desecularization of the World. Míchigan: Eerdmans. Borroughs, Williams. 2009. La revolución electrónica. Buenos Aires: La Caja Negra. 
Braunstein, Peter, and Michael William. 2002. Imagine Nation: The American counterculture of the 1960s and '70s. London: Routledge.

Casanova, José. 2009. "Religion, politics and gender equality: Public religions revisited". Report for the United Nations Research Institute for Social Development, paper number 5.

Casanova, José. 2000. Religiones públicas en el mundo moderno. Madrid: PPC. Centro Mundial Bahá'í. 2005. Una misma Fe. Madrid: Arca Editorial.

Díaz-Salazar, Rafael, Fernando Velasco, and Salvador Ginés. 2006. Formas modernas de religión. Madrid: Alianza Editorial.

Duplessy, Lucien. 1959. El espiritu de la civilización. Madrid: Taurus.

Estruch, Joan. 2015. Entendre les religions: una perspectiva sociologica. Barcelona: Mediterránea.

Ferguson, Neil. 2019. The Square and the Tower: Networks and Power, from the freemasons to Facebook. London: Penguin Books.

Fukuyama, Francis. 1989. "The end of history?". The national interest 16: 3-18.

Garcés, Marina. 2017. Nueva Ilustración radical. Barcelona: Anagrama.

García, Sergio. 2016. Desafios del sistema de seguridad colectiva de la ONU: análisis sociológico de las amenazas globales. Madrid: Centro de Investigaciones Sociológicas.

García, Sergio. Nov. 2018. "Es la tecnología la solución al cambio climático". In the newspaper Periodista digital.

González, H. M., Vega, W. A., Williams, D. R., Tarraf, W., West, B. T., \& Neighbors, H. W. 2010. "Depression care in the United States: too little for too few". In Archives of general psychiatry 67, $\mathrm{n}^{\circ}$ 1: 37-46.

Grames, Carlos. 2012. El puño invisible. Madrid: Taurus.

Habermas, Jürgen. 2011. "The political. The rationale meaning of a questionable inheritance of political theology". En The Power of Religion in Public Sphere, Edited by Eduardo Mendieta and Jonathan VanAntwerpen (eds), 15-33. Columbia: Columbia University Press.

Habermas, Jürgen. 2009. Ay Europa. Madrid: Trotta.

Harvey, David. 1998. La condición de la posmodernidad. Madrid: Amorrortu.

Huntington, Samuel. 2002. El choque de civilizaciones. Madrid: Tecnos.

Joas, Hans. 2008.Do we need religion? On the experience of self-transcendence. Colorado: Paradigm Publishers.

Joas, Hans, and Robert Bellah. 2012. The axial age and its consequences. Massachusetts: The Belknap Press of Harvard University Press.

Kerr, Clark. 2001. The uses of the University. Massachusetts: Harvard University Press.

MacIntyre, Alasdair. 1985. Marxism and Christianity. Notre Dame: University of Notre DamePress.

McLuhan, Marshall. 1996. Comprender los medios de comunicación. Barcelona: Paidós.

Mills, Wright. 1959. Sociological imagination. Oxford: Oxford University Press. 
Moghadam, Assaf. 2003. A Global Resurgence of Religion? Third edition. Massachusetts: Weatherhead Center for International Affairs of Harvard University.

Pew Research Center. 2017. "The religious typology: a new way to categorize Americans by religion". Report on religion and public life. https://www.pewforum.org/2018/08/29/the-religious-typology/.

Rakodi, Carole, and Severine Deneulin. 2011. "Revisiting Religion: Development Studies Thirty Years On”. World Development 39, $\mathrm{n}^{\circ}$ 1: 4554.

Roldán Gómez, Isabel. 2017. "Lo postsecular: un concepto normativo". Política $y$ Sociedad 54, $\mathrm{n}^{\mathrm{o}}$ 3: 851-867.

Rosa, Harmut. 2019. "Teoría de la resonancia como concepto fundamental de una sociología de la relación con el mundo". Revista diferencias 7: 71-81.

Sadin, Eric. 2019. La siliconización del mundo: la irresistible expansión del liberalismo digital. Buenos Aires: La Caja Negra.

Sánchez-Bayón, Antonio. 2016. Religión civil estadounidense. Madrid: Sindéresis.

Sánchez-Bayón, Antonio. 2016. "Una historia filosófica de la identidad estadounidense". Bajo Palabra. II Época 18: 209-236.

Sánchez-Bayón, Antonio, Carlos Fuente, and Gloria Campos. 2018. "Crisis identitaria estadounidense ante su paradoja posmoderna: quiebra de American civil religion y riesgo transoccidental". Cauriensia 13: 619-636.

Tamayo, Juan José. 2011. Otra teología es posible: pluralismo religioso, interculturalidad y feminismo. Barcelona: Herder.

Sergio García-Magariño I-Communitas, Instituto de Investigaciones Sociales Avanzadas Universidad Pública de Navarra

Edificio Jerónimo de Ayanz. Arrosadia. Calle Tajonar, 22, 31006

Pamplona-Iruña (España) https://orcid.org/0000-0002-0562-3800 
